\title{
Investigation of the visual and content validity and the reliability of the Persian version of the Movement Imagery Questionnaire for Children MIQ-C
}

Aali, M, B. (M.A). University of Tehran, Tehran, Iran

Shahbazi, M. (Ph.D). University of Tehran, Tehran, Iran

Received: 2017 - 8 - 6

Accept: $2018-4-25$

\begin{abstract}
The movement imagery helps to learn various sports skills if persons have a reasonable imagery about how doing that skill and the command be carved on the brain. The main aim of the current study is to investigate the visual and content validity as well as the reliability of the Persian version of the Movement Imagery Questionnaire for Children MIQ-C. The main questionnaire was translated into the Persian by using the Translation-back Translation method. In order to standardize and validate the questionnaire, 10 elites in the field of the motor imagery and sports psychology, filled the questionnaires in order to determine the content validity ratio (CVR) and the content validity index (CVI). After a primitive study, the necessary modifications were applied.The questionnaire reliability was investigated by the test-retest reliability method and the Cronbach's alpha. Results indicated that the CVR and CVI are 0.62 and 0.79 , respectively, which confirms the validity of the questionnaire. The reliability was confirmed by the internal consistency method which value was obtained higher than 0.7. For evaluating the ability of children in motor imaginary, a reliable method should be used.According to obtained results of the current work, the questionnaire benefits from a suitable reliability and validity.
\end{abstract}

Keywords: Reliability; Questionnaire; Children movement imagery; Content validity index; Content validity ratio. 


\title{
MIQ-C اعتباريابى نسخهُ فارسى يرسشنامه تصويرسازى حركتى كودكان
}

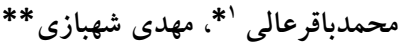

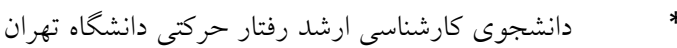 \\ دانشيار دانشخاه تهران
}

هدف از يزوهش حاضر بررسى روايى صورى، محتوايى و بِايايى نسخهُ فارسى يرسشنامه تصويرسازى حركتى كودكان

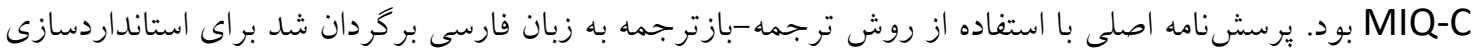
و معتبركردن يُرسشنامه، ده نفر از متخصصان رفتارحركتى و روانشناسى ورزشى يرسشنامها را به منظور تعيين نسبت روايى محتوا و شاخص روايى محتوا تكميل كردند. بعد از يك مطالعه مقدماتى، اصلاحات لازم لحاظ شد. سبس بايايى



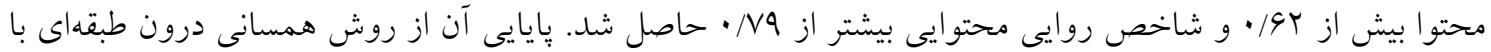
مقدار بيشتر از •V/• تأييد شد. براى سنجش توانايى تصويرسازى كودكان مىبايست از يك ابزار قابل اعتماد استفاده

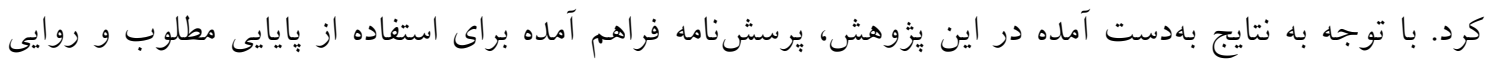
مناسبى برخوردار است. وازمهاى كليدى: بايايى، برسشنامه، تصويرسازى حركتى كودكان، شاخص روايى محتوا، نسبت روايى محتوا. 
تصويرسازى ذهنى در رأس همه تجربههاى حسى قرار دارد؛ اما توانايى انسان در تعميق، به ياد آوردن و دستكارى تصاوير ذهنى

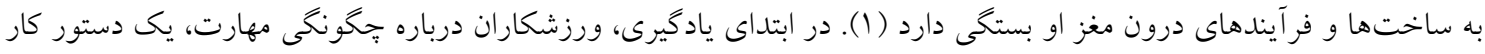
ضعيف دارند؛ سبس مى تواند از تصويرسازى ذهنى كمى بخيرند. تصويرسازى حركتى، شبيه به يك ويتامين كمكى عمل مى كند و جايخزين نيازهاى تغذيهاى نيست؛ بلكه فقط مكمل است. تصويرسازى زمانى بهصورت يكى كارآيى عمل مى كند؛ كه طرح آن

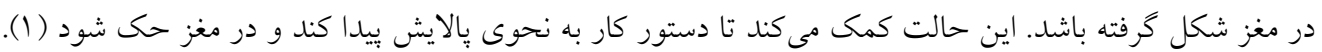
براساس كفته ريجاردسون (1999)، تصويرسازى ذهنى يك فرآيند درونى هوشيارانه است كه تجربه زندكى واقعى را در غياب تجربه ادراكى و حسى زندگى واقعى تقليد مى كند. احتمالاً مهمترين عامل در خصوص اثر بخشى تصويرسازى، توانايى افراد در استفاده از آن است (Y). تحقيقات نشان دادهاند موقعى كه افراد از لحاظ توانايى تصويرسازى در سطوح بالاترى هستند، تمرين

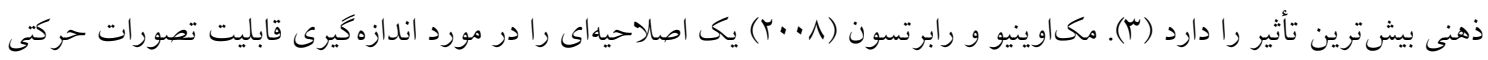
تهيه كردند و به اين نتيجه رسيدند كه به دليل تفاوتهاى انفرادى توانايى تصويرسازى افراد، اين ضرورىى است كه ظرفيت انفرادى هر فرد قبل از انجام يكى مطالعه كه شامل تصويرسازى حركتى مىباشد، اندازهيرى شود. در محيطهاى ورزشى، تصويرسازى، را مى توان به عنوان ابداع يا تكرار يكى تجربه در نظر گرفت كه از طريق اطلاعات ذخيره شده در حافظه يك فرد توليد مىشود. اين تجربه مىتواند شامل مشخصه هاى حسى، ادراكى و عاطفى باشد كه حتى مى تواند در غياب يكى محرى واقعى اتفاق بيفتد. معمولاً اين تصورات باعث ايجاد اثرات فيزيولوزيكى و روانى بر روى فردى مىشود كه از اين تصويرسازى استفاده مى كند (†). بنابراين، يززوهشخران قبل از اجراى يزوهش توانايى تصويرسازى شركت كنندگان را به منظور كزينش آنها ارزيابى مى كنند (ه). علاوه بر اين، توانايى تصويرسازى ذهنى عامل مهمى در تشخيص ورزشكاران نخبه و غيرنخبه و يا موفق و كمموفق مىباشد (9). توانايى تصويرسازى خوب اغلب به صورت تصويرسازى واضح و قابل كنترل تعريف مىشود. لازم است، ورزشكاران بدانند كه

تصويرسازى ذهنى، يك مهارت محسوب مىشود. بنابراين وضوح و قابليت كنترل آن با تمرين و تكرار بهبود مى يابد (1).

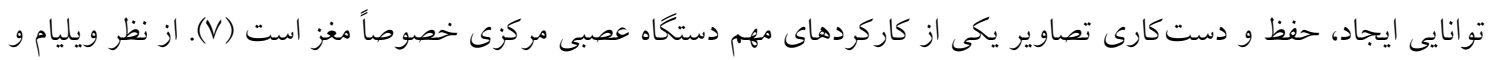
همكارانش، تعيين اينكه كدام نماى تصويرسازى (حركتى، ديدارى درونى يا بيرونى) براى هر فرد مناسبتر است، بسيار مهم و ضرورى است، زيرا كه منجر به بهترين نتيجه در بهكار كيرى تصويرسازى مىشود. با توجه به نوع تصويرسازى، ورزشكاران اصولاً به أ حالت توصيف مىشوند (ديدارى، حركتى، شنوايى و بويايى) كه تصويرسازى ديدارى و حركتى بيشتر مورد استفاده ورزشكاران در شرايط مختلف، قرار مى گيرند (N). تصويرسازى ديدارى شامل اطلاعاتى، درباره آنجه كه افراد در تصاوير مىبينند و از دو بُعد مى توان آن را انجام داد: بُعد درونى، فرد خودش را به صورت اول شخص مىبيند، در حقيقت در اين حالت، بخششهاى انفرادى

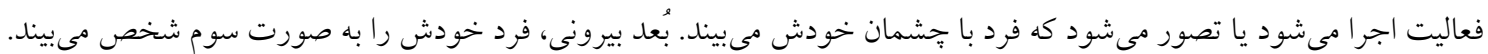
در اين حالت، افراد در جايگاه شخص بيننده قرار دارند، كويى كه فعاليت را در خارج بدن خودشان مى بينند (9). نماى حركتى به اين صورت است كه فرد از انجام يك عمل جه احساسى مى كند، مانند كشيده شدن يك ماهيجه در حال انقباض در حال بالا رفتن از يلهها. اين احساس درونى شامل آكَاهى از موقعيت و حركات بدن، بهعنوان حس عمقى يا جنبشى و همجِنين استقامت و تلاش

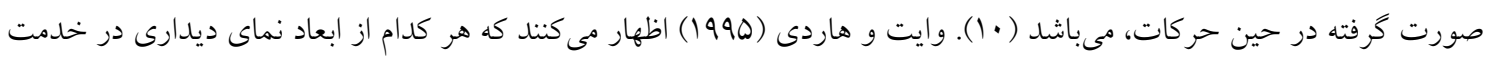

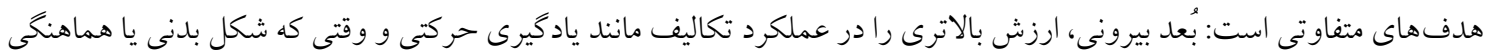

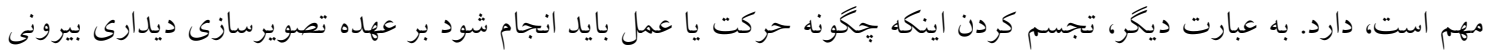
است. بُعلد درونى ارزش بالاترى را در فعاليتهاى باز دارد كه در آنها مفهوم زمانى مهم است (فرد توانايى تجسم مفهوم فضايى و و زمانى را دارد). نماى حركتى تأثير بيشترى را بر روى آموزش و عملكرد ورزشكاران، وقتى كه نتايج حركت مرتبط با اجراى

ورزشى مىباشند، دارد (11). تمامى افراد قادر به ايجاد و استفاده از تصويرسازى اند. اما برخى افراد در اين مورد از ديخران بهترند. توانايى ساخت اين تصويرسازى و كيفيت تصوير ساخته شده بهعنوان توانايى تصويرسازى شناخته مىشود. اين توانايى ميزان استفاده شخص از تصويرسازى و همجنين ميزان موفقيت ناشى از استفاده را مشخص مى كند (Y (I). بنابراين ويلسون و همكاران (Y (Y) به منظور اندازهيرى دقيق 


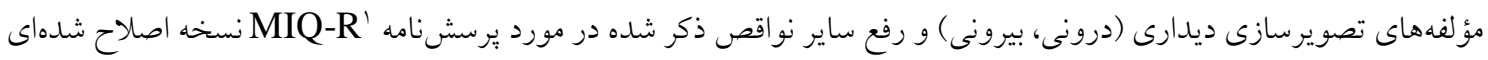



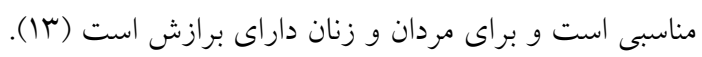

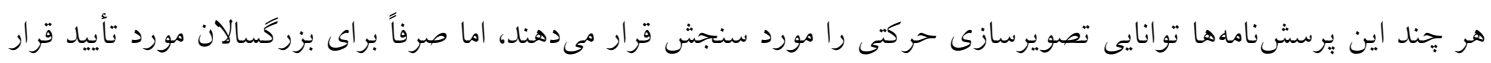

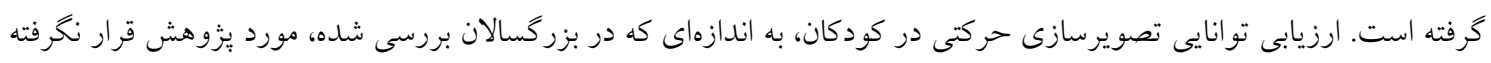



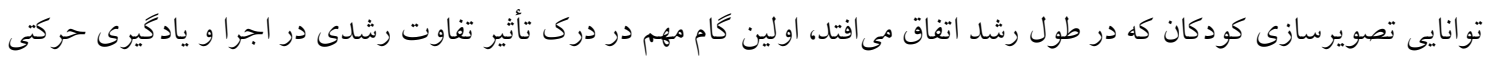

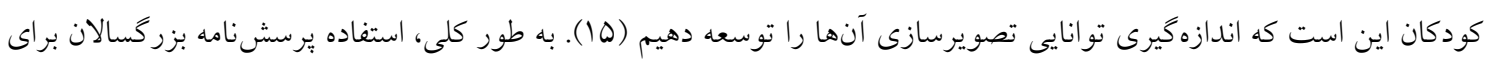

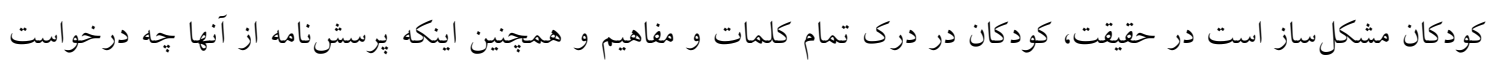

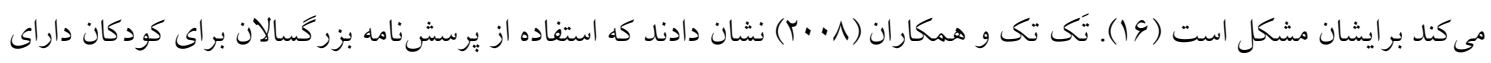

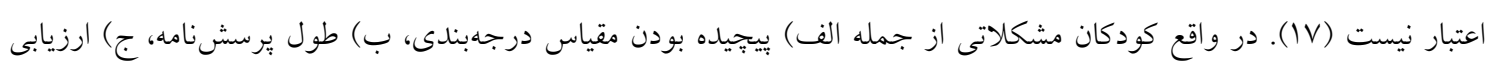

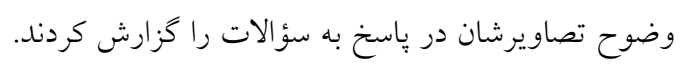

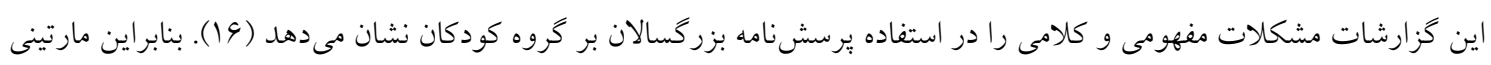

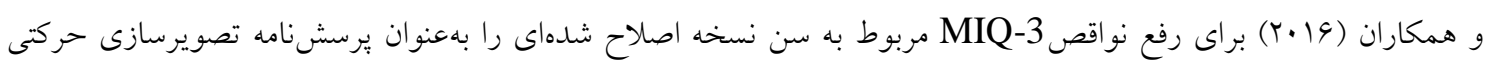



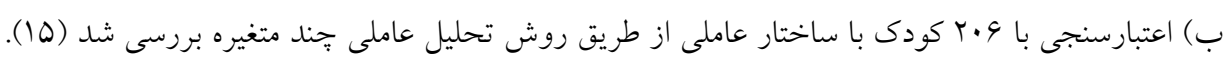

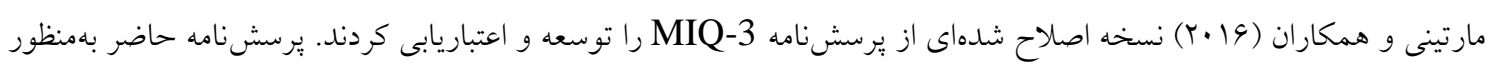

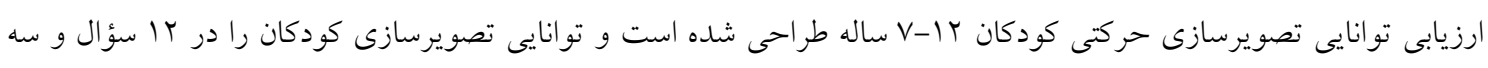



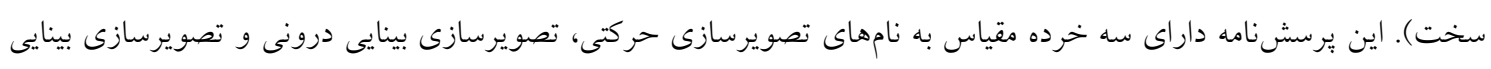

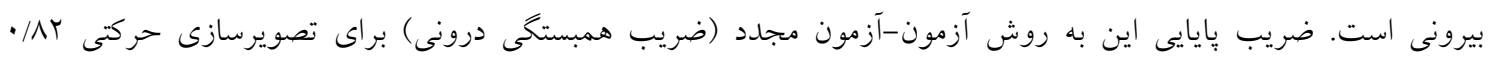

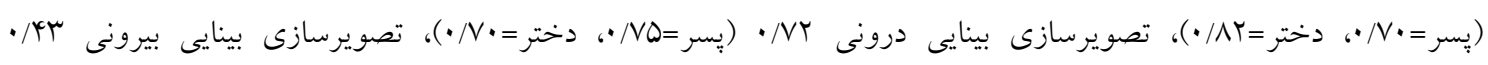

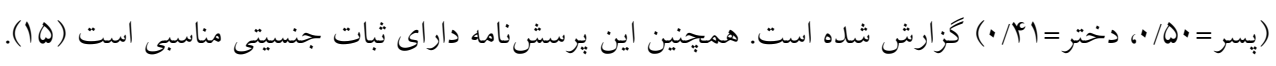



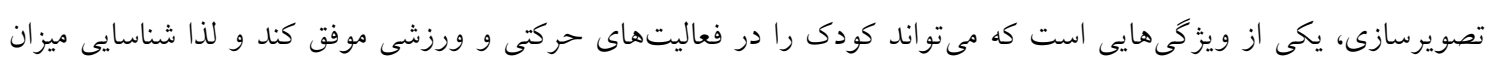

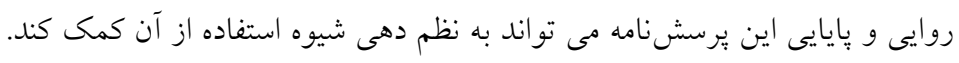

\section{روششناسى}

يُّوهش حاضر به اعتباريابى نسخه فارسى يرسشنامه تصويرسازى حركنى كودكان در جامعه ايرانى مى يردازد. جمع آورى دادهها

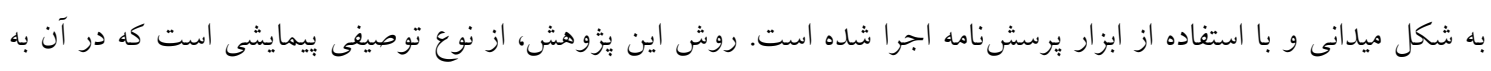

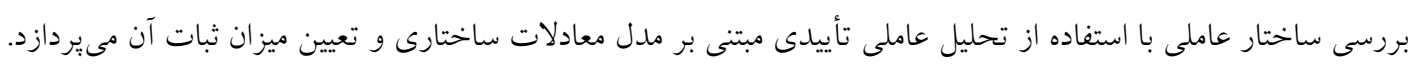





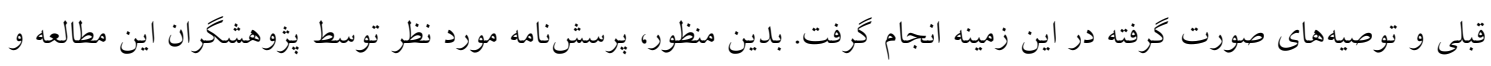

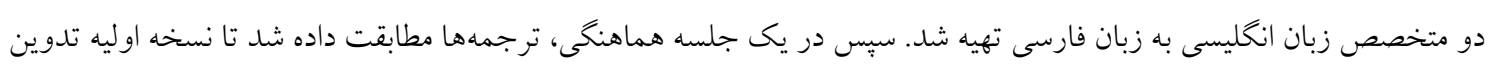

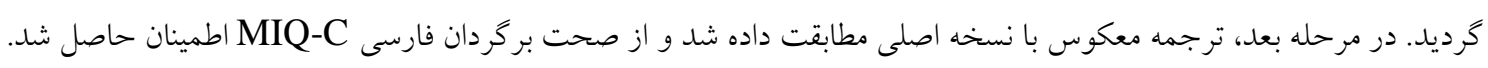

1. Revised Movement Imagery Questionnaire
2. Movement Imagery

Questionnaire-3
3. Movement Imagery

Questionnaire for Children

4. Translation-back Translation 
براى سنجش روايى محتوايى' كمى و كيفى، پِ از تأييد صحت ترجمه، •ا نفر از افراد خبره در زمينه رشته تربيتبدنى و علوم

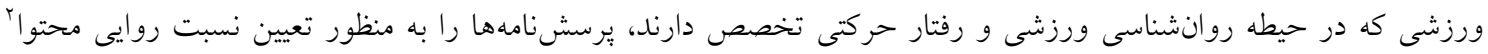
(CVI) تكميل كردند و سبس نسبت روايى محتوا و شاخص روايى محتوا به را محاسبه كرديم.

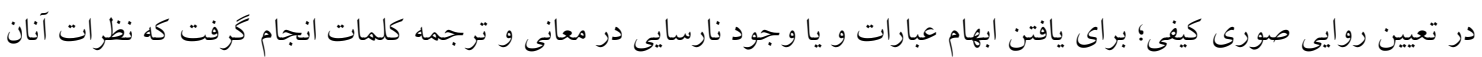

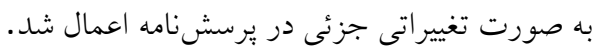
محاسبه شاخص CVR سبب مى كردد تا محقق از انتخاب مهمترين و بهترين محتوا به لحاظ آمارى اطمينان حاصل نمايد. در اين

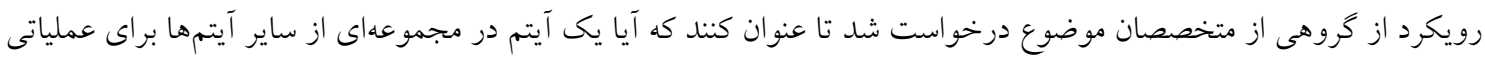

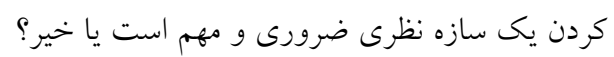

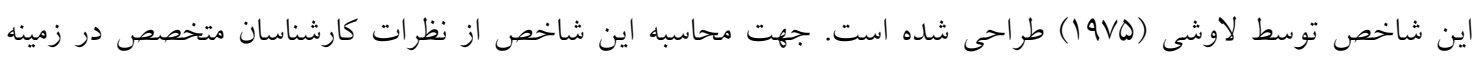

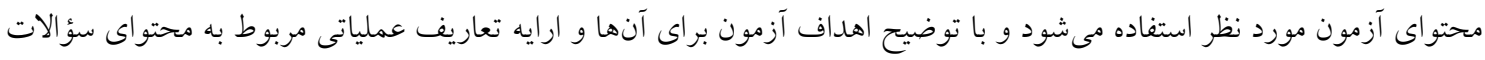

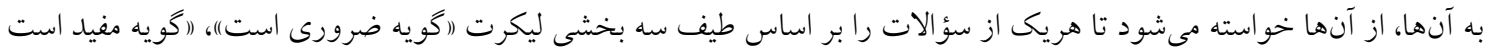

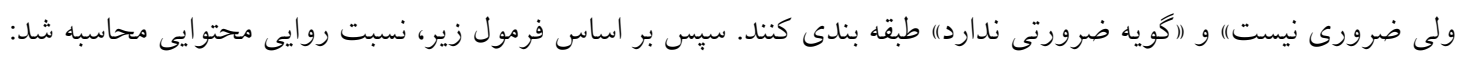

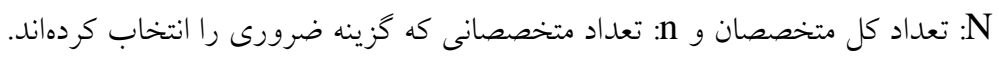

$$
\begin{aligned}
& C V R=\frac{n-\frac{N}{2}}{\frac{N}{2}} \\
& \text { فرمول ا مربوط نسبت روايى محتوا }
\end{aligned}
$$

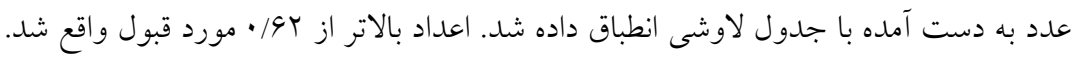

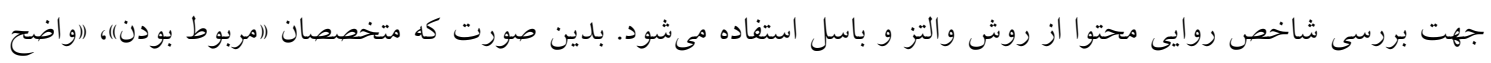
بودن) و (ساده بودن) هر كويه را بر اساس يك طيف جهار ليكرتى مشخص مى كنند. متخصصان مربوط بودن هر كويه را از نظر

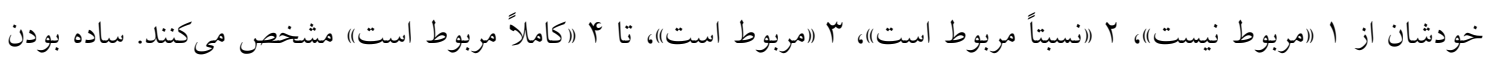

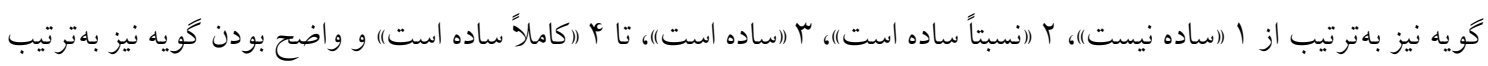

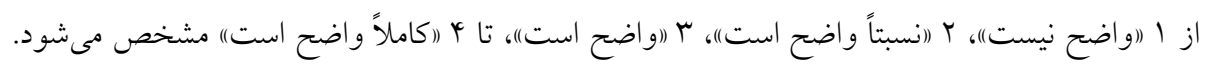

$$
\text { CVI = }
$$





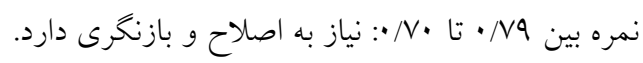

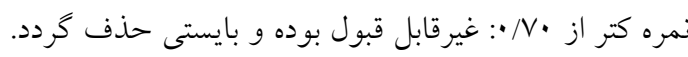

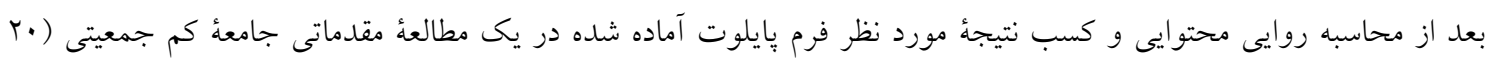



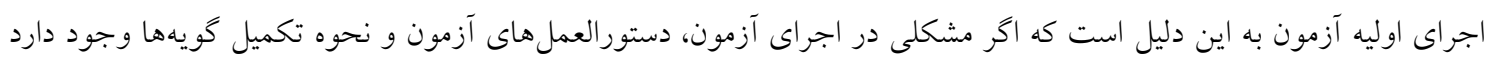

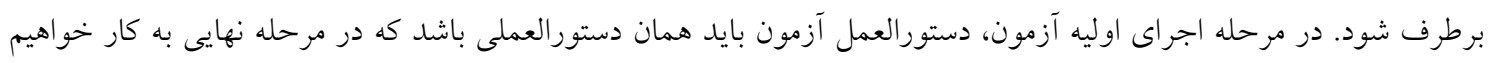

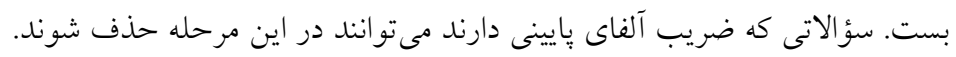

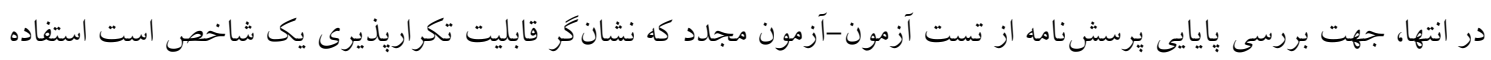

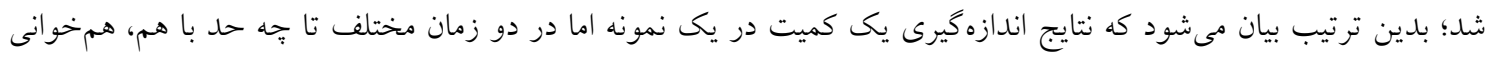


براى اين منظور نسخه روا شده پِرسشنامه توسط جهل كودى V تا Y ا سال تكميل شد؛ سيس بعد از دو هفته از آنها خواسته شد

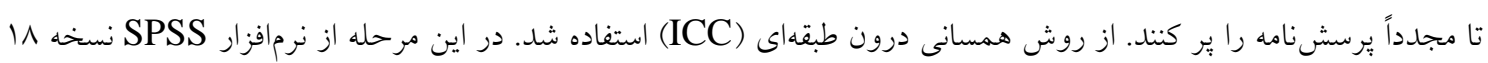
جهت بردازش دادهها استفاده گرديد.

\section{كافتهها}

نتايج CVR حاكى از آن بود كه بيشتر سؤالات از نظر گروه متخصصان از روايى محتوايى قابل قبول برخوردارند و سؤال ه نياز به بررسى هاى تكميلى ديخرى داشت. بنابر اين، بِ ازيج بازنخرى مجاد در سؤ الات، اصلاحات مورد نظر انجام شد و در نهايت نمره

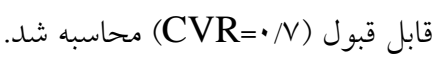
نتايج بهدست آمده در جدول النشان مىدهد كه شاخص روايى محتوا در تمام سؤالات، هم به صورت بررسى هر سؤال و هم به

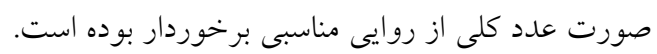

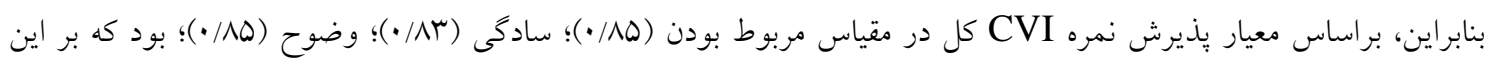

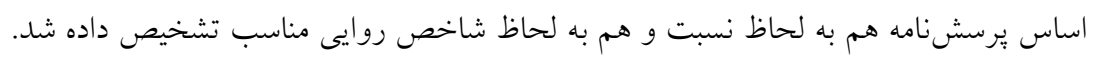

\begin{tabular}{|c|c|c|c|c|c|}
\hline بذيرش يا & $\begin{array}{c}\text { CVI } \\
\text { (وضوح) }\end{array}$ & $\begin{array}{c}\text { CVI } \\
\text { (سادכى) }\end{array}$ & $\begin{array}{c}\text { CVI } \\
\text { (مربوط) } \\
\text { بودن) }\end{array}$ & CVR & سؤال \\
\hline يذ يذش & $\cdot / 9$ & $\cdot / 1$ & $\cdot / \Lambda$ & $\cdot / \Lambda$ & 1 \\
\hline يذ يذيرش & $\cdot / \Lambda$ & $\cdot / \Lambda$ & $\cdot / \Lambda$ & $\cdot / \Lambda$ & r \\
\hline يذ يذش & $\cdot / \Lambda$ & $\cdot / \Lambda$ & $\cdot / \Lambda$ & $\cdot 19$ & $r$ \\
\hline يذّيرش & $\cdot / \Lambda$ & $\cdot / \Lambda$ & $\cdot / \Lambda$ & $\cdot / \Lambda$ & $k$ \\
\hline يذيرش & $\cdot / \Lambda$ & $\cdot / \Lambda$ & $\cdot / \Lambda$ & $\cdot / 4$ & $\Delta$ \\
\hline يذيرش & $\cdot / \Lambda$ & $\cdot / \Lambda$ & $\cdot / \Lambda$ & $\cdot / \Lambda$ & 9 \\
\hline يذيرش & $\cdot / \Lambda$ & $\cdot / 9$ & $\cdot / \Lambda$ & $\cdot 19$ & V \\
\hline يذيرش & $\cdot / 9$ & 1 & $\cdot / 9$ & $\cdot / \Lambda$ & $\wedge$ \\
\hline يذيرش & $\cdot / \Lambda$ & $\cdot / \Lambda$ & $\cdot / 9$ & .19 & 9 \\
\hline يذيرش & $\cdot / \Lambda$ & $\cdot / \Lambda$ & 1 & $\cdot / \wedge$ & 1. \\
\hline يذيرش & 1 & $\cdot / \Lambda$ & $\cdot / 9$ & $\cdot / \Lambda$ & 11 \\
\hline يذيرش & 1 & $\cdot / 9$ & $\cdot / 9$ & .19 & Ir \\
\hline قابل قبول & - / $\Delta \Delta$ & • & $\cdot / \Lambda \Delta$ & $\cdot / V$ & كل \\
\hline
\end{tabular}

همانطور كه در جدول ب مشاهده مىشود، نتيجة محاسبات انجام شده براى برآورد يَايايى زمانى عاملهاى برسشنامه نشان داد كه مقدار ضريب آلفا برى خردهمقياسها از V/ • بالاتر است.




جدول r. نتايج آلفاى كرونباخ براى مطالعه مقدماتى

\begin{tabular}{|c|c|c|c|c|}
\hline \multicolumn{2}{|c|}{ نتايج پايايى } & \multirow[b]{2}{*}{ تعداد نفرات } & \multirow[b]{2}{*}{ شماره سؤالات } & \multirow{2}{*}{ 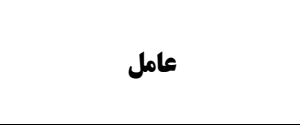 } \\
\hline ضريب آلفا & تعداد سؤال & & & \\
\hline .191 & 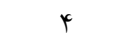 & 4. & $1 \cdot-V-Y-1$ & تصويرسازى حركتى \\
\hline$\cdot / v$ & r & 4. & $11-\Lambda-Q-r$ & تصويرسازى ديدارى درونى \\
\hline$\cdot / V 4$ & r & $\varphi$ & $1 r-9-9-r$ & تصويرسازى ديدارى بيرونى \\
\hline
\end{tabular}

همان گونه كه در جدول فوق مشاهده مىشود عوامل تصويرسازى ديدارى بيرونى و تصويرسازى ديدارى درونى از شاخص بايايى

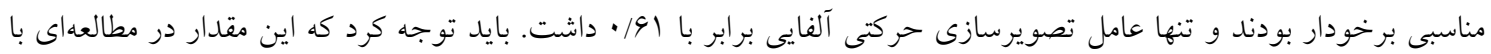
جمعيت • r نفر قابل قبول است.

\begin{tabular}{|c|c|c|}
\hline \multicolumn{2}{|c|}{ نتايج باياى زمانى } & \multirow{2}{*}{ 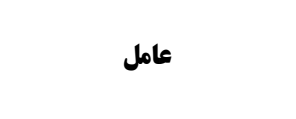 } \\
\hline \multicolumn{2}{|c|}{ همبستكى درون طبقهاى (ICC) } & \\
\hline$\cdot / N Y$ & أ انفر & تصويرسازى حركتى \\
\hline$\cdot / \mathrm{V}$ & 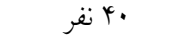 & تصويرسازى ديدارى درونى \\
\hline$\cdot / \mathrm{VI}$ & 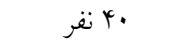 & تصويرسازى ديدارى بيرونى \\
\hline
\end{tabular}

همان كونه كه مشاهده مىشود بالاترين ضريب ICC مربوط به عامل تصويرسازى حركتى است و پايينت ترين ضريب نيز متعلق

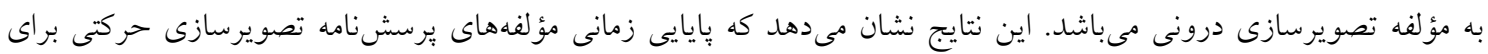
كودكان مناسب است.

\section{بحث و نتيجه كيرى}

اساس و مبناى انجام هر تحقيق استفاده از ابزارهاى اندازهيرى روائو و باياست و توضيح و تفسير نتايج يزوهش به روايى ابزار به

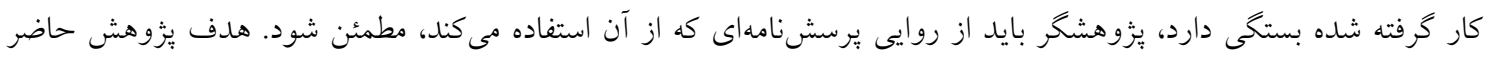

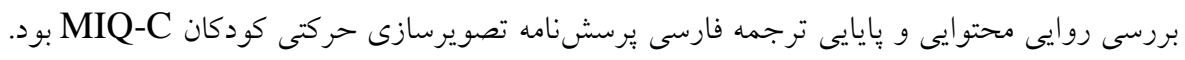

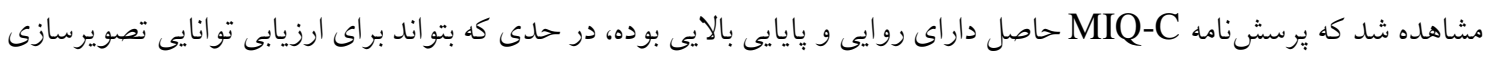

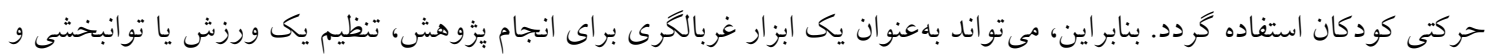

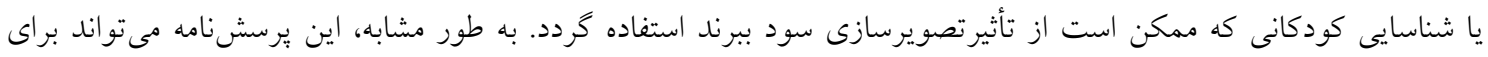

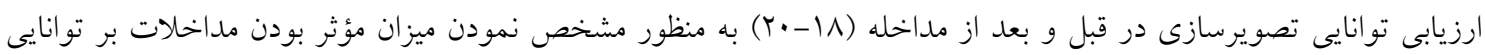

تصويرسازى مورد استفاده قرار خيرد (ه) (1).

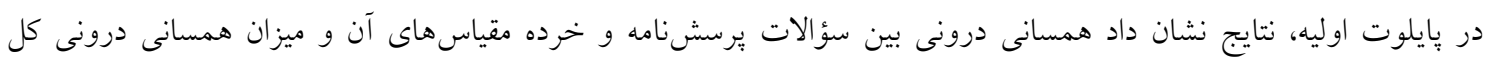

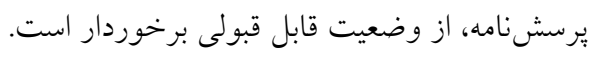



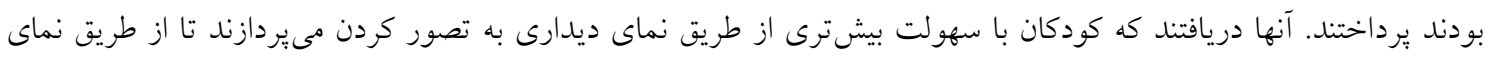


خارستانى و همكاران (T/ج1) در يزوهشى با عنوان (مقايسه تأثير تصويرسازى خاص شناختى و عمومى شناختى بر اجراى مهارت



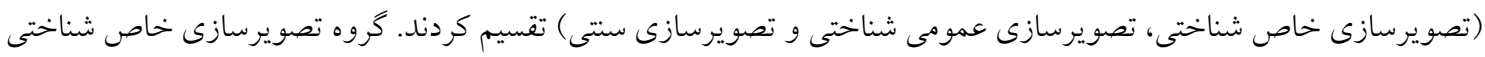

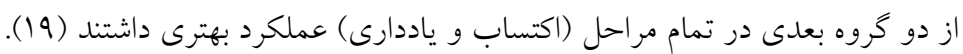



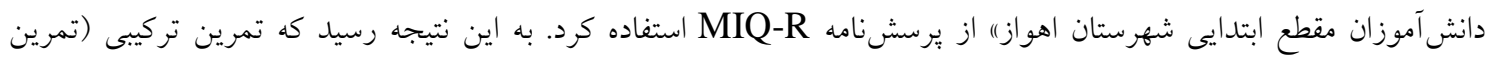

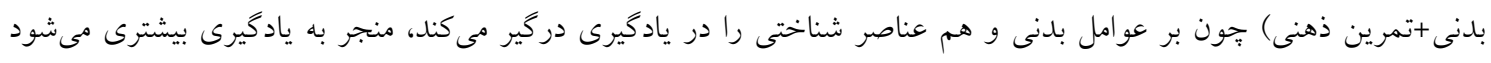

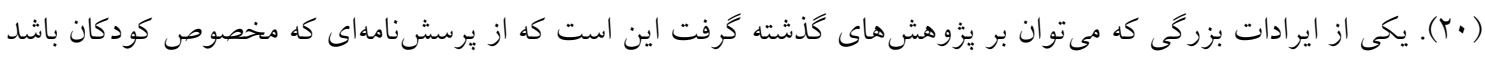
| استفاده نشده است. جنين ابزار ارزيابى مى تواند اطلاعات مهمى در زمينه تفاوتهاى احتمالى در توانايى تصويرسازى حركتى در ميان كودكان داراى

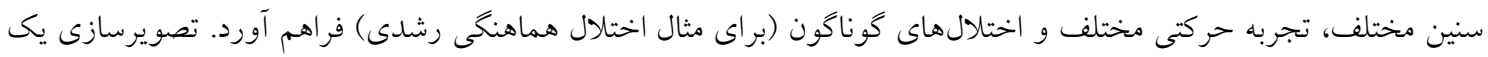

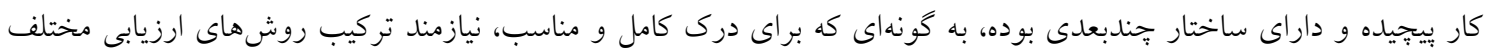

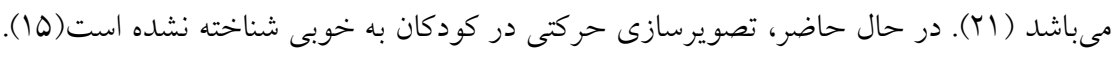

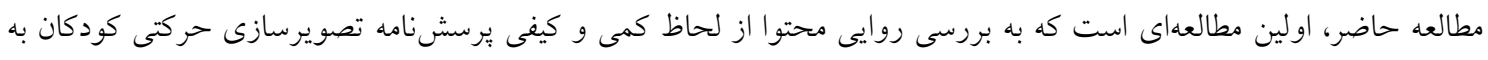

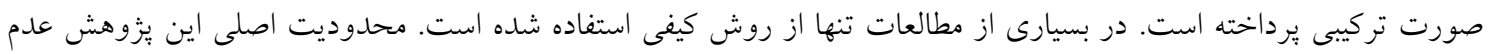

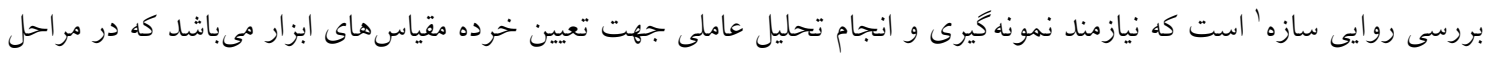

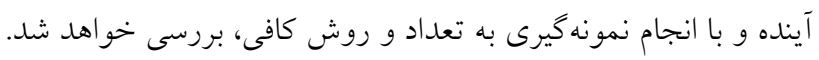

1. Yadolahzadeh A. Psychology of mental imagery in sport. Tehran: Publishers Hatmi; 2015, In Persian.

2. Richardson A. Mental practice: A review and discussion part II. Research Quarterly American Association for Health, Physical Education and Recreation. 1967;38.Vr-หrr:(r)

3. Isaac AR. Mental practice: Does it work in the field? The Sport Psychologist. 1992.

4. Morris T, Spittle M, Watt A. Imagery in Sport (Chap. 10. Technical Aids to Imagery, pp. 237-266). Champaign, IL: Human Kinetics. 2005.

5. Cumming J, Ramsey R I .Imagery interventions in sport. Advances in Applied Sport Psychology. 2008:5.

6. Murphy L. Effects of a cognitive specific imagery intervention on the soccer skill performance of young athletes aged 11--12 and 13--14: A developmental perspective. 2006.

7. Hojati A, VaezMousavi M, Khabiri M. Psychometric Properties of Persian Version of the Movement Imagery Questionnaire-3. Journal of Sport Psychology Studie. 2016;14:16-1, In Persian.

8. Weinberg RS, Gould D. Foundations of Sport and Exercise Psychology, 6E: Human Kinetics; 2014.

9. Holmes $P$, Calmels $C$. A neuroscientific review of imagery and observation use in sport. Journal of motor behavior. 2008;40(5):433-45.

10. Callow N, Waters $A$. The effect of kinesthetic imagery on the sport confidence of flatrace horse jockeys. Psychology of Sport and Exercise. 2005;6(4):443-59.

11. Féry $Y-A$, Morizot $P$. Kinesthetic and visual image in modeling closed motor skills: The example of the tennis serve. Perceptual and motor Skills. 2000;90(3):707-22.

12. Cumming J, Williams SE . The role of imagery in performance. Handbook of sport and performance psychology. 2012:213-32. 
13. Williams SE, Cumming J, Ntoumanis N, Nordin-Bates SM, Ramsey R, Hall C. Further validation and development of the movement imagery questionnaire. Journal of Sport \& Exercise Psychology. 2012;34.

14. Gabbard C. Studying action representation in children via motor imagery. Brain and Cognition. 2009;71(3):234-9.

15. Martini R, Carter MJ, Yoxon E, Cumming J, Ste-Marie DM. Development and validation of the Movement Imagery Questionnaire for Children (MIQ-C). Psychology of Sport and Exercise. 2016;22:190-201.

16. Stadulis RE, MacCracken MJ, Eidson TA, Severance C. A children's form of the competitive state anxiety inventory: The CSAI-2C. Measurement in Physical Education and Exercise Science. 2002;6(3):147-65.

17. Taktek K, Zinsser N, St-John B. Visual versus kinesthetic mental imagery: Efficacy for the retention and transfer of a closed motor skill in young children. Canadian Journal of Experimental Psychology/Revue canadienne de psychologie expérimentale. 2008;62(3):174.

18. Quinton ML, Cumming J, Gray R, Geeson JR, Cooper A, Crowley H, et al. A PETTLEP imagery intervention with young athletes. Journal of Imagery Research in Sport and Physical Activity. 2014;9.09- ₹v:(1)

$$
\begin{aligned}
& \text { 19. خارستانى، مهرزاد؛ اسماعيلى، آبدر؛ قطبى ورزنه، احمد مقايسة تأثير تصويرسازى خاص شناختى }
\end{aligned}
$$

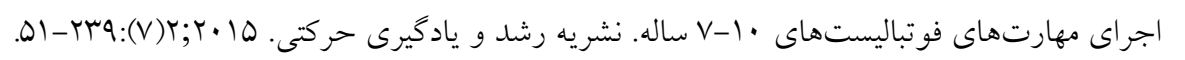

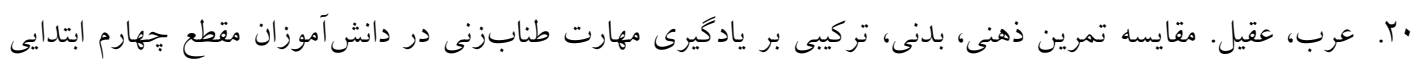

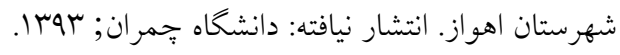

21. Collet C, Guillot A, Lebon F, Maclntyre T, Moran A. Measuring motor imagery using psychometric, behavioral, and psychophysiological tools. Exercise and sport sciences reviews. 2011;39(2):85-92. 